\title{
The Influence of Employee Recognition on Employee Engagement: The Moderating Role of Salary Satisfaction
}

Esther Mensema Ewool, Samuel Awuni Azinga, Naail Mohammed Kamil

To Link this Article: http://dx.doi.org/10.6007/IJARAFMS/v11-i3/10554 DOI:10.6007/IJARAFMS /v11-i3/10554

Received: 11 June 2021, Revised: 13 July 2021, Accepted: 29 July 2021

Published Online: 16 August 2021

In-Text Citation: (Ewool et al., 2021)

To Cite this Article: Ewool, E. M., Azinga, S. A., \& Kamil, N. M. (2021). The Influence of Employee Recognition on Employee Engagement: The Moderating Role of Salary Satisfaction. International Journal of Acdemic Research in Accounting, Finance and Managment Science, 11(3), 433-456.

Copyright: (c) 2021 The Author(s)

Published by Human Resource Management Academic Research Society (www.hrmars.com)

This article is published under the Creative Commons Attribution (CC BY 4.0) license. Anyone may reproduce, distribute, translate and create derivative works of this article (for both commercial and non-commercial purposes), subject to full attribution to the original publication and authors. The full terms of this license may be seen at: http://creativecommons.org/licences/by/4.0/legalcode

Vol. 11, No. 3, 2021, Pg. 433 - 456 


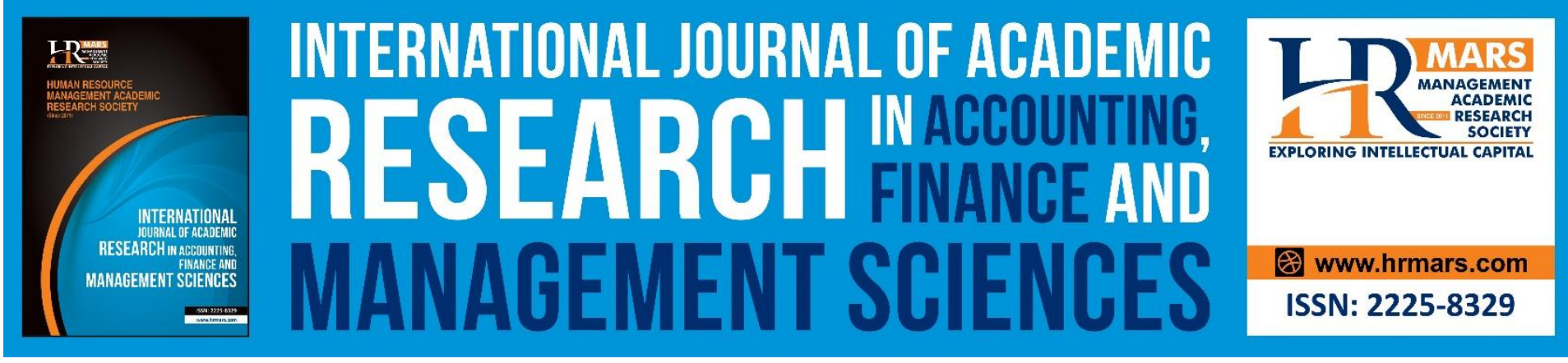

\title{
The Influence of Employee Recognition on Employee Engagement: The Moderating Role of Salary Satisfaction
}

\author{
Esther Mensema Ewool, Samuel Awuni Azinga, Naail \\ Mohammed Kamil \\ Department of Human Resource and Organizational Development, Kwame Nkrumah \\ University of Science and Technology, Kumasi, Ashanti Region, Ghana \\ Email: esthermewool@gmail.com
}

\begin{abstract}
The present study attempts to empirically examine, and contribute new knowledge to the existing literature, pertaining the association between employee recognition, salary satisfaction, and employee engagement, with emphasis on the moderating role of salary satisfaction in the Ghanaian banking system. A quantitative research approach was employed in this study, whereby a sample of 455 respondents comprising employees of consolidated bank Ghana from Kumasi and Accra central were sampled using a simple random sampling technique. Employing SPSS and AMOS versions 24.0, structural equation modeling SEM was used to analyze the collected data. Out of the four (4) main hypotheses of this study, three (3) were supported whilst one (1) was not. In particular, after controlling for four relevant demographic variables, namely educational level, tenure, employee level and income, the study revealed that employee recognition has a positive effect on salary satisfaction and negative effect on employee engagement; Salary satisfaction also has a positive influence on employee engagement and positively moderates the relationship between employee recognition and employee engagement. The study concludes that the impact of employee recognition on employee engagement is stronger in light of increased salary satisfaction. Several other implications from the study were further discussed.
\end{abstract}

Keywords: Employee Recognition, Employee Engagement, Salary Satisfaction, Job Characteristics, Banks

\section{Introduction}

Every business needs to maximize employee integration using all available strategies, including enhancing employee engagement, recognition and salary satisfaction especially in a time when market competition and macro-economic conditions pose dire effects on businesses on a global scale. Employee engagement is simply defined as the level of involvement of employees in business-oriented activities (Vorina, Simonič \& Vlasova, 2017). Because businesses can only meet their goals and achieve performance goals through their operational activities, they need to always achieve the highest possible level of employee 
MANAGEMENT SCIENCES

Vol. 11, No. 3, 2021, E-ISSN: 2225-8329 @ 2021 HRMARS

engagement. Paying employees high salaries and allowances have been confirmed to predict employee engagement. Logically because employees are more likely to be satisfied and committed to the organization when they receive higher pay, but some researchers (Salisu, Chinyio, \& Suresh, 2015; Yaseen, 2013) have indicated that, paying employees highly does not necessarily lead to salary satisfaction. This is because employees tend to have rising expectation for their income when their salaries increase. These researchers have averred that giving employees the recognition they expect is, however, necessary to engender salary satisfaction since employee recognition compensates for low job income. The researchers have realized that these thoughts have theoretical underpinnings that need to be tested empirically in terms of how salary satisfaction moderates the association between employee recognition and employee engagement. An assessment of this moderation influence can unveil implications for theoretical modification and practice, especially in some sectors (e.g. banking) where high pay overshadows other necessary employee recognition practices (Ghana banking Survey, 2015).

It could further be asserted that, employees' expectations with respect to their recognition and remuneration would be affected by their job tenure. To explain, new employees or relatively new employees would not expect high salaries; neither would they expect recognition from their employers at the onset of their employment. This is possibly so because new employees admit the need for them to use their first few years in the organization to demonstrate their worth, or at least contribute a quota and build experience that deserves high pay and recognition. Employees who have spent several years on the job, on the other hand, would think they have made unending sacrifices for the business and therefore deserve the best remuneration and recognition. The objectives of this study were to:

- Analyze the influence of employee recognition on employee engagement.

- Examine the association between employee recognition and salary satisfaction.

- Assess the influence of salary satisfaction on employee engagement

- Analyze the moderation influence of employee recognition and salary satisfaction on employee engagement.

The following hypotheses were formulated for the studies:

* $H_{1}$ - Employee recognition makes a significant positive influence on employee engagement so that employees' engagement increases as their recognition increases.

* $\mathrm{H}_{2}$-Employee recognition makes a significant positive effect on salary satisfaction so that salary satisfaction improves as employee recognition increases.

* H3 - Salary satisfaction makes a significant positive influence on employee engagement in the sense that, employees' engagement increases as their salary satisfaction increases.

* H4 - the influence of recognition on employee engagement is significantly positively moderated by salary satisfaction.

This reasoning has the backing of some studies conducted in Ghana and other countries. Mensah et al (2016) focused on Ghanaian workers, found out that job tenure predicted employee expectation and commitment. Mends-Brew and Asiamah (2018) also recently argued and found that expectations regarding recognition and pay on the job are influenced by the number of years the employee has contributed to the growth of the organization. In Slovenia, Vorina et al (2017) found that employees' salary expectations were strongly 
MANAGEMENT SCIENCES

Vol. 11, No. 3, 2021, E-ISSN: 2225-8329 @ 2021 HRMARS

associated with number of years served or job tenure. This evidence is shared by Shonubi, Abdullah, Hashim \& Hamid (2016) who did a related study in Malaysia.

The above evidence indicates that job income can influence salary satisfaction and employee recognition and as a result confound the moderation role of salary satisfaction being tested in this study. It is believed that this confounding influence is also exerted by any job attribute that changes with job tenure such as education, job income, and employee rank. In a demonstrative study recently conducted, it was found that any job characteristic that changes over a period can change with time (Asiamah, Mends-Brew \& Boison, 2019). The findings from some studies (Asiamah, 2017; Mends-Brew \& Asiamah, 2018) conducted in Ghana also support this evidence. Controlling for these job characteristics would therefore not only lead to the best effect estimates but also has the possibility of unveiling salient implications for practice. It has also been reported that controlling for potential confounders in a crosssectional research is not optional and is necessary if accurate findings are to be reached (Asiamah et al., 2019; Vorina et al., 2017).

\section{Literature Review Definition of Concepts}

Employee recognition has been a strong part of the human resource management literature as it is seen in theory as an intrinsic motivation factor. It has been defined as the level of importance attached by the employer to the job role of an employee (Muchai \& Benson, 2014). Alternatively, it is the degree to which the employer and other employees in the organization see the employee as an important part of the organizational workforce (Shonubi et al., 2016). The second definition treats employee recognition as a condition influenced by both the employer (i.e. management of the organization, including the employee's immediate boss) and colleagues. It can thus be said to be a measure of how important the role of the employee is to his/her employer, colleagues, and superior. When recognition is high, the employee is valued and appreciated for every action taken in line with organizational goals. Finally, as job motivation factor, employee recognition is a determinant of employee engagement.

One of the roles of human resource managers and coaches is to enhance employee engagement as a step towards improving employee and organizational performance. Employee engagement is one of the most important organizational performance indicators because it serves as a basis by which employees play a part in the organization. If employees should contribute their quota to performance of the organization, they can only do so through their roles by getting involved in individual and team tasks (Kimutai \& Sakataka, 2015). It can be said, therefore, that without adequate engagement of the employee in the organization, performance may leave much to be desired.

Employee engagement has been explained as the degree to which the employee is fond of and consequently gets involved in the core business activities of an organization (Vorina et al., 2017). It is also referred to as the attraction between the employee and the activities of the organization resulting from and in a sense of happiness and belonging (Kimutai \& Sakataka, 2015). The two explanations suggest that employee engagement is founded on either fondness for the organization or a sense of belonging to it. Unarguably, a sense of belonging develops from fondness for the organization; hence it can be said that employee engagement is fundamentally driven by likeness for the organization. Many previous studies have confirmed that employee engagement is a key determinant of positive behaviours 
MANAGEMENT SCIENCES

Vol. 11, No. 3, 2021, E-ISSN: 2225-8329 @ 2021 HRMARS

(Kimutai \& Sakataka, 2015; Salleh \& Memon, 2015; Vorina et al., 2017), including overall job satisfaction and pay satisfaction.

Earnings from a job in monetary terms could be the most important benefit to employees, especially those at lower employee levels (Malik, Danish \& Munir, 2012), basically because these benefits provide the means for satisfying many other needs. For example, an employee who earns highly on the job has a higher ability to acquire shelter, clothing, and other necessities and save for future use. Employees are therefore not wrong when they work for or demand higher pay on the job. Salary or pay is the employee's monthly gross income, fringe benefits and allowances that come in the form of money (Ndungu, 2017). In some instances, net income is used as an indicator of pay rather than gross salary because taxes and social security contributions do not immediately or directly come to the employee. So, a more conservative definition of salary is net monthly pay, fringe benefits and allowances received by the employee (Mansoor et al., 2015).

The fondest expectation of employees is to earn enough income on the job (Mussie, Kathryn \& Embaye, 2013) thus their satisfaction can greatly be influenced by pay. This idea brings to mind the term salary satisfaction, also sometimes known as pay satisfaction. Salary satisfaction has been explained as the degree to which an employee is content with his or her pay or earnings on the job (Salleh \& Memon, 2015). Often times, salary satisfaction increases as one's pay increases, but a more accurate way to understand salary satisfaction is to see it as an outcome of other benefits such as recognition, flexible job design, organizational justice, job security, among others (A'yuninnisa \& Saptoto, 2015). This is another way to say that pay satisfaction may be driven mainly by the size of the employee's salary, but the above factors also contribute to it. This means that employees who receive a balance of high salary and the foregoing conditions would be more satisfied than their colleagues who receive only high salaries.

\section{Theoretical Framework}

\section{The Two Factor Theory of Motivation (TTM)}

This theory was first formulated by Frederick Herzberg in 1959 to delineate some factors that influence employee behaviour. The theory asserts that there are different factors that influence job satisfaction and dissatisfaction at the workplace. It thus distinguishes between motivational factors and hygiene factors. Motivators are intrinsic job factors such as recognition, achievement, and personal growth that are essential to satisfaction. Nonmotivators or hygiene factors are extrinsic job variables such as job security, pay, fringe benefits, and working conditions, among others. The hygiene factors do not directly predict job satisfaction, but their absence can cause dissatisfaction due to their pacifying tendencies. According to the theory, employee recognition (an intrinsic factor) is part of the expectation of employees. When met therefore, employee engagement can lead to job satisfaction.

\section{The Social Exchange Theory (SET)}

This theory was originally developed by George Homans, and explains the rational for employee behaviours. The theory posits that employee behaviours are the result of costbenefit analysis of the employee's contribution to the organization. It assumes that every employee works for a good pay; hence the employee always compares his contribution to his pay. An employee is encouraged to put up positive behaviours like job satisfaction and commitment when his benefits from the organization are at par or exceed his/her contribution. This notion is based on the idea that the employee has expectations (e.g. 
MANAGEMENT SCIENCES

Vol. 11, No. 3, 2021, E-ISSN: 2225-8329 @ 2021 HRMARS

earning good pay) that the employer must necessarily meet. Failure of the employer to meet this expectation can thus lead to negative behaviours like employee disengagement and inconsistent positive behaviours. Though the theory has been criticised for not sufficiently touching on the non-financial aspects of employees' needs, it remains a reliable theory for studying social and organizational behaviours. Interestingly, it underpins the relationship being tested in this study.

\section{The Theory of Reasoned Action (TRA)}

This theory was developed by Martin Fishbein and Icek Ajzen in 1967 to explain why employees would behave in a particular way. It explains the relationship between attitudes and behaviours from an organization perspective and explains how employee behaviours develop from environmental and socio-economic factors. It argues primarily that whatever the employee does is the result of the impact of factors such as rewards (e.g. pay) that encourage a particular course of behaviour from the employee. To illustrate, employees would behave in a particular way because of the pay and incentives associated with this type of behaviour. It could thus be argued that whatever the employee does or does not do in an organization can be influenced by policies that specify rewards for key behaviours. The theory was later adapted and expanded to address discrepancies in the A-B relationship with two models, namely the Theory of Planned Behaviour and Reasoned Action Approach.

\section{Employee Recognition, Employee Engagement, Salary Satisfaction and their relationship with TTM, SET, TRA}

The influence of employee recognition on employee engagement can be explained from the points of view of TTM and TRA. The TTM asserts employee recognition as an intrinsic job factor that can lead to job satisfaction if provided by the employer. The theory also posits that job satisfaction is the basis of employees' willingness to continue working with the organization. The desire to continue working with the organization translates into engagement in organizational activities, which is a positive behaviour. According to the TRA, positive behaviours such as employee engagement and commitment are outcomes of conditions in an organizational environment, including policies that oblige management to recognise outstanding employees. The TTM and TRA therefore imply that employee engagement can increase as employee recognition increases.

The SET assumes that the expectations and needs of employees are diverse and range from active to passive employee behaviours. It adds that every employee's need is important because each will contribute to satisfaction if met. The TTM also recognises good pay as an extrinsic work factor that can reduce dissatisfaction. The SET and TTM together therefore implies that employees will exhibit satisfaction when their pay is high. Satisfaction that results from good pay is basically salary satisfaction (A'yuninnisa \& Saptoto, 2015). The TRA assumes that a good work condition can influence multiple positive behaviours from employees. For instance, an employee who is not paid well but is given flexible job conditions and has high job security can be satisfied and would therefore want to identify with the organization. Similarly, appreciating and recognising the efforts of employees can lead to employee engagement, even if pay is relatively poor. If so, a satisfied employee can demonstrate high salary satisfaction even if his/her pay is not good enough. In this regard, employee recognition can be considered precursor to salary satisfaction. 
MANAGEMENT SCIENCES

Vol. 11, No. 3, 2021, E-ISSN: 2225-8329 @ 2021 HRMARS

Salary satisfaction is not a positive employee behavior only but is also desirable. The TTM argues that when employees are satisfied because of their pay, they report lower dissatisfaction. Maximum job satisfaction is at the level where employee dissatisfaction is lowest (Korir \& Kipkebut, 2016). So, though salary satisfaction results from an intrinsic job factor, it can maximise satisfaction, employee retention, commitment and the degree to which employees participate in organizational activities. Most employees salary satisfaction can be attributed to good pay, and this is rightly so because salary satisfaction is typically about the impact of pay and incentives on employee behaviours and the needs of the employee. Given the theoretical argument made above, the other part of salary satisfaction may be due to the ability of the employer to meet the non-financial needs and expectations of the employee. Thus, salary satisfaction may have unique qualities not embedded in employee engagement that predict staff engagement. In this regard, salary satisfaction can complement the impact of employee recognition on employee engagement, thereby making the influence of recognition on employee engagement stronger. This theoretical deduction portrays the positive influence of employee engagement on salary satisfaction and indicates that the impact of employee recognition on employee engagement can be positively moderated. The next section reviews related studies that have confirmed or adapted the above theoretical position.

\section{Empirical Review}

This section is focused on reviewing related studies as a basis of identifying gaps in the literature. The section has three parts: (a) the relationship between employee recognition and employee engagement; (b) the relationship between employee recognition and salary satisfaction; and (c) the association between salary satisfaction and employee engagement.

\section{The Influence of Employee Recognition on Engagement}

Akafo and Boateng (2015) studied employee recognition in relation to performance outcomes in Ghana. In their study, they examined the influence of reward and recognition on employee motivation, which included indicators of engagement. In their study, a quantitative research approach was employed. The study's population was staff of private tertiary institutions in Ghana, and the stratified sampling method was used to select 157 participants. Questionnaires were used to gather data, and data analysis was conducted using SPSS. Pearson's correlation coefficient, descriptive statistics, and analysis of variance (ANOVA) were used to present findings. The researchers found that recognition was positively associated with satisfaction, motivation, and employees' involvement in organizational activities. Recognition and reward in the institutions were considered fair by most staff members but some concerns were raised regarding allowances and fringe benefits. For this reason, the levels of staff involvement and satisfaction have room for improvement. The main weakness associated with their study was the fact that the impact of job characteristics like education, tenure and income on employees' opinions was not considered and adjusted for.

In India, Baskar and Prakash (2015) conducted a similar study in which the association between reward and recognition and motivation was examined. A quantitative design was adopted by the researchers in the setting of the study. Participants were 50 employees of private industrial firms selected using the convenience sampling method. Descriptive statistics, Pearson's correlation test, and linear regression analysis were used to present findings. The study found that recognition of employees was directly related to employee 
MANAGEMENT SCIENCES

Vol. 11, No. 3, 2021, E-ISSN: 2225-8329 @ 2021 HRMARS

engagement, satisfaction and general motivation. Thus, employees' organizational engagement increases as their recognition increases.

In Pakistan, Danish and Usman (2010) carried out a study to evaluate influence of recognition on employee satisfaction and level of engagement. The researchers employed a descriptive quantitative design in which cross-sectional data was collected using a self-reported questionnaire. Participants were employees from a wide scope of industrial firms, including banks and manufacturing firms. The purposive sampling mechanism was used to select 250 participants, but only 220 questionnaires were analyzed. Descriptive statistics and Pearson's correlation were used to present findings. The study indicated that recognition has a positive correlation with staff engagement, which means that staff engagement increases as recognition increases. The level of engagement was moderate because recognition was relatively low.

It is interesting to note that the above studies reviewed and many other studies (Muchai \& Benson, 2014; Mussie et al., 2013; Ndungu, 2017; Shonubi et al., 2016) point towards a positive association between recognition and employee engagement. Even so, very few studies were conducted in Ghana and no identifiable study was carried out in the banking sector.

\section{The Association between Salary Satisfaction and Recognition}

A'yuninnisa and Saptoto (2015) conducted examined the influence of recognition on salary satisfaction. In their study, they applied a quantitative design to test key hypotheses. The setting of the study was an automobile company in Indonesia. Participants were individuals who were hired as full-time employees for at least 3 months. The purposive sampling procedure was used to select 183 participants. Pearson's correlation test and structural equation modelling was used to analyze the data or test hypotheses through AMOS. The study found that pay satisfaction was positively associated with employee engagement but negatively associated with the intention to leave. This result means that employees' intention to leave increases as their salary satisfaction decreases. In addition, employees' pay satisfaction increases as their recognition increases. A more detailed analysis was conducted by Mussie et al (2013), who included key variables. The researchers employed a crosssectional (correlational technique) and data from the US, Vietnam, and Malaysia. The simple random sampling method was used to select participants as follows: U.S. ( $n=457$ ), Malaysia $(n=347)$ and Vietnam $(n=391)$. Questionnaires were used to gather data while Pearson's correlation and regression analysis were used to present findings. The study confirmed that pay satisfaction is positively associated with recognition in line with the study of A'yuninnisa and Saptoto (2015). There was even a stronger association between pay and satisfaction, indicating that compensation in the organizations strongly predicted employee satisfaction.

Salleh and Memon (2015) studied the relationship between salary satisfaction and employee engagement. Unlike other studies reviewed, this study employed a review approach whereby the literature was comprehensively reviewed to draw on theoretical and conceptual provisions in the literature. Thoughts shared were supported with relevant empirical evidence like those confirmed in the foregoing studies. The researchers produced a conceptual model that treats salary satisfaction as an outcome of employee recognition. Given the increasing concern of researchers (Asiamah et al., 2019) regarding the misleading influence of potential confounders on associations tested in cross-sectional studies, their failure to capture alternative explanatory variables in their model is a major weakness. The above evidences are interesting, but studies focused on assessing the relationship between salary satisfaction and 
MANAGEMENT SCIENCES

Vol. 11, No. 3, 2021, E-ISSN: 2225-8329 @ 2021 HRMARS

recognition is relatively few. To the best of the researcher's knowledge, none has been focused on Ghana, which makes the current study an important contribution to the literature.

\section{The Association between Salary Satisfaction and Staff Engagement}

More recently, Vorina et al. (2017) carried out a study to assess the influence of salary satisfaction on employee engagement in Slovenia. They employed the quantitative design and cross-sectional survey approach. Participants were 594 employees in public and private organizations in Slovenia. A self-reported questionnaire was used to gather data, and Pearson's correlation test and multiple linear regression were used to present findings. Their study confirmed that salary satisfaction makes a positive influence on employee engagement, connoting that employee engagement increases as salary satisfaction increases.

In Ghana, Preko and Adjetey (2014) also conducted a study to examine the influence of compensation and salary satisfaction among sales executives of commercial banks on staff engagement. Their study was a quantitative design that adopted a self-reported questionnaire to gather data. The purposive sampling technique was used to select 50 participants across three banks: Fidelity Bank, Eco Bank and Standard Chartered Bank. The study confirmed a strong association between employees' salary satisfaction and engagement, which affirms the outcome of Vorina et al. (2017). Salleh and Memon (2015) also used a comprehensive review technique to demonstrate the linkage between salary satisfaction and employee engagement. The researchers drew on theoretical and conceptual provisions in the literature to show the significance of the said association. Thoughts shared were supported with relevant empirical evidence like those confirmed in the foregoing studies. The researchers produced a conceptual model that treats employee engagement as an outcome of salary satisfaction. They thus insinuate that increasing staff's salary satisfaction can increase engagement.

\section{The Conceptual Model}

The conceptual model of the association between employee recognition, salary satisfaction, and employee engagement is presented in figure 1. Often, employees are recognized by giving them intangible benefits (e.g. plaudits, public commendation, special privileges) and/or tangible ones (e.g. allowances, special cheques, vehicle, etc.). Any of the two forms of recognition are appreciated by employees (Akafo \& Boateng, 2015; Danish \& Usman, 2010). 


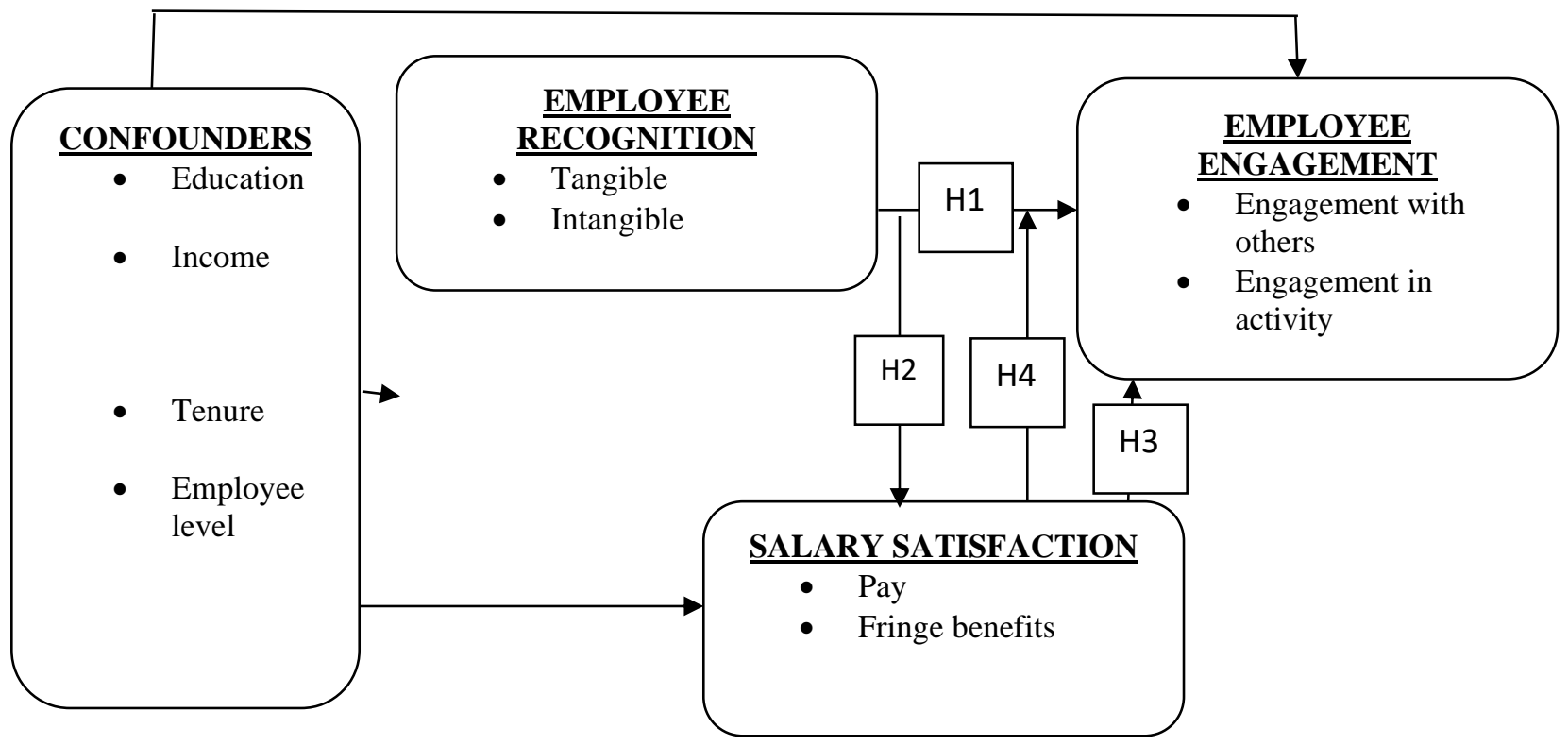

Figure 1. A conceptual model of the association between employee recognition, salary satisfaction, and employee engagement. $\mathrm{H}=$ Hypothesis

The above model is subject to potential confounding variables, which are job characteristics of employees. For example, salary changes with job tenure (Asiamah et al., 2019; Asiamah, Mensah, \& Danquah, 2018); hence it is likely that the influence of salary satisfaction on engagement is merely an outcome of prolonged service in the organization. Apart from salary, the employee's education and tenure change with tenure and salary size (Asiamah, 2017). Similarly, employees would need to save money over a period of time to be able to finance higher education, and they would need time to be promoted to higher ranks. In agreement with these illustrations, tenure, job income, employee rank, and education are captured in the model (Figure 1) as potential lurking variables.

\section{Materials and Methods}

\section{Design, Population and Sample}

This study employed the cross-sectional and correlational approaches to examine the association between employee recognition, salary satisfaction, and employee engagement. The study was conducted as a quantitative design, specifically a cross-sectional correlational technique. The study setting was Kumasi and Accra Central, and participants were employees of Consolidated Bank Ghana Limited. A total of 455 employees who met some selection criteria and were selected using the simple random sampling technique responded through a self-reported questionnaire (Appendix).

\section{Variables and their Operationalization}

The main variables of this study were employee recognition, employee engagement, and salary satisfaction. The main dependent variable was employee engagement, whereas employee recognition was the independent variable. Salary satisfaction was captured as the moderating variable. Employee recognition was measured using a standard scale borrowed from Mussie et al. (2013). This scale is associated with seven Likert levels that range from strongly disagree (1) to strongly agree (7). Similarly, employee engagement was measured using Likert scale items borrowed from Vorina et al. (2017) and associated with five descriptive anchors, namely strongly disagree (1) to strongly agree (5). Salary satisfaction was 
MANAGEMENT SCIENCES

Vol. 11, No. 3, 2021, E-ISSN: 2225-8329 @ 2021 HRMARS

also measured using pay satisfaction Likert scale borrowed from Salleh and Memon (2015). This scale also has seven descriptive anchors that range from not satisfied (1) to extremely satisfied (7). The other variables measured are gender, education, tenure, employee level, and income. Gender was measured as the sex (i.e. male -1 ; female -2 ) of respondents. Education was the highest formal education acquired by the participant at the time of data collection, and tenure was the number of years the employee had worked in the organization. Employee level was the rank of the employee, and income was the gross monthly earning of the worker. Gender was treated as a dichotomous continuous variable and was therefore dummy-coded to be incorporated into the parametric test. Other confounders were measured and coded as continuous variables.

\section{Instrumentation and Psychometric Properties of Measures}

A self-reported questionnaire was used to gather data. The questionnaire had four main sections, with the first section dedicated to salary satisfaction. Employee engagement was measured in the second section, whereas the third and fourth sections presented questions on employee recognition and demographic variables respectively. Validity and reliability were ensured by using a resilient procedure demonstrated elsewhere (Asiamah et al., 2018) to assess the psychometric properties of the measurement scales.

\section{Data Analysis Method}

Data was analyzed using Amos and IBM SPSS 24 (IBM Inc., New York, U.S.A.). SPSS was used to perform exploratory analysis, including correlational and descriptive analyses. Amos, on the other hand, was used to test hypotheses through structural equation modelling. Data analysis was in two phases. In the first phase, data was screened for outliers using descriptive statistics and the z-score procedure applied elsewhere (Mends-Brew \& Asiamah, 2018). A confirmatory factor analysis (CFA) procedure was also applied to assess the psychometric properties of the measurement scales. Multivariate normality of data, which is a requirement for using SEM, was also assessed and confirmed through the CFA procedure. Other assumptions verified are uni-dimensionality and multi-collinearity. Outcomes of these exploratory analyses are shown in the section where findings are presented. The second phase of data analysis presents results based on objectives and hypotheses. All hypotheses were tested concurrently using SEM rather than hierarchically in order to reduce type I error. The confounding variables were also captured in the SEM model to maximise the chance of reaching precise estimates. Significance of effects was at $p<0.05$. Pearson's correlation test was used to examine bivariate correlations between relevant variables.

\section{Results and Discussion}

Table 1 is the estimation of the necessary psychometric properties. Aside Cronbach's alpha (CA), all other parameters are for validity determination. Cronbach's alpha is an indicator of internal consistency and is expected to be higher or equal to 0.7. Kelava (2016), emphasized on acceptable reliability if alpha (Cronbach's alpha) exceeds 0.7 . It can be seen that all factors yielded $C A$ values greater than 0.7 ( $C A>0.7)$. The factor loadings values of each construct also are larger than 0.7. Moreover, for convergent and discriminant validity, it is expected that Average Variance Estimate (AVE) must be greater than $50 \%$ and Maximum Shared Variance (MSV) less than Average Variance Estimate (Asiamah et al., 2018). With regards to the confirmatory factor analysis (CFA) the measurement scale used for this study was adequate.The criteria for internal reliability and validity were met. Table 2 shows the statistics 
MANAGEMENT SCIENCES

Vol. 11, No. 3, 2021, E-ISSN: 2225-8329 @ 2021 HRMARS

for model fitness. According to some researchers (Asiamah et al., 2018; Kelava, 2016), model fit is good when the following thresholds are met; $p>0.05 ;$ GFI $>0.95 ; A G F I>0.80$ and RMSEA $<0.05$. Kelava (2016) further considered a model as moderate and bad if RMSEA $<0.05-$ 0.10 and RMSEA>0.10 respectively (holding other metrics constant).

Table 1. Reliability and Validity Indicators

\begin{tabular}{|c|c|c|c|c|c|}
\hline Construct & Factor & $\begin{array}{l}\text { Cronbach's } \\
\text { Alpha }\end{array}$ & $\begin{array}{l}\text { Average } \\
\text { Variance } \\
\text { Estimate }\end{array}$ & $\begin{array}{l}\text { Maximum } \\
\text { Shared } \\
\text { Variance }\end{array}$ & $\begin{array}{l}\text { Average } \\
\text { Shared } \\
\text { Variance }\end{array}$ \\
\hline \multirow{4}{*}{ Salary Satisfaction } & PS & 0.909 & 0.727 & 0.112 & 0.074 \\
\hline & SFB & 0.925 & 0.740 & 0.112 & 0.076 \\
\hline & SPPFC & 0.908 & 0.726 & 0.112 & 0.074 \\
\hline & $\begin{array}{l}\text { All } \\
\text { scale }\end{array}$ & 0.958 & ---- & ---- & ---- \\
\hline \multirow{3}{*}{$\begin{array}{l}\text { Employee } \\
\text { Engagement }\end{array}$} & EO & 0.863 & 0.690 & 0.106 & 0.070 \\
\hline & EA & 0.916 & 0.733 & 0.106 & 0.075 \\
\hline & $\begin{array}{l}\text { All } \\
\text { scale }\end{array}$ & 0.937 & --- & --- & --- \\
\hline $\begin{array}{l}\text { Employee } \\
\text { Recognition }\end{array}$ & $\begin{array}{l}\text { All } \\
\text { scale }\end{array}$ & 0.903 & --- & --- & --- \\
\hline
\end{tabular}

Note: ${ }^{--V}$ Values not relevant or available. PS - Pay satisfaction; SFB - Satisfaction with Fringe Benefits; SPPFC - Satisfaction with Pension and Provident Fund Contribution; EO engagement with others; $E A$ - engagement in activities

Table 2: Model Fit Statistics

\begin{tabular}{|c|c|c|c|c|c|c|}
\hline Model & $\chi^{2}$ & $P$ & $\begin{array}{l}\text { Root Mean Square } \\
\text { Error } \\
\text { Approximation }\end{array}$ & Tucker-Lewis Index & $\begin{array}{l}\text { Goodness- } \\
\text { of-Fit Index }\end{array}$ & $\begin{array}{l}\text { Adjusted } \\
\text { Goodness- } \\
\text { of-Fit Index }\end{array}$ \\
\hline 1 & 73.01 & 0.011 & 0.229 & 0.877 & 0.877 & 0.881 \\
\hline 2 & 22.12 & 0.010 & 0.099 & 0.899 & 0.896 & 0.898 \\
\hline 3 & 16.00 & 0.031 & 0.078 & 0.901 & 0.899 & 0.922 \\
\hline
\end{tabular}

Note: Model 1 = Salary Satisfaction Measurement Model; Model 2 = Employee Engagement Measurement Model; Model 3 = Employee Recognition Measurement Model

The results showed that the models did not meet this threshold and may seem as poorly fit, but Kelava (2016) contends that this outcome does not affect the structural (i.e. hypothetical) model significantly if the structural model is of a good fit and all constructs are reliable.

Table 3 shows the correlation between employee engagement, salary satisfaction, and employee recognition. The table shows that there exists a significant weak positive correlation between employee engagement and salary satisfaction $[r=0.186 ; p=.0000]$. This signifies that an increase in employee engagement will result to a positive increase in salary satisfaction. Salary satisfaction is positively associated (strong) with employee recognition [ $r=$ $0.670 ; p=0.0000$ ]. Thus, an employee is highly recognized as his/her salary increases. Salary satisfaction is positively correlated to education, employee level, and job income but negatively correlated to job tenure. Employee recognition does not correlate to job tenure and likewise employee engagement. 
INTERNATIONAL JOURNAL OF ACADEMIC RESEARCH IN ACCOUNTING, FINANCE AND

MANAGEMENT SCIENCES

Vol. 11, No. 3, 2021, E-ISSN: 2225-8329 @ 2021 HRMARS

Table 3. Correlation between employee engagement, salary satisfaction, and employee recognition

\begin{tabular}{lllllllll}
\hline Variable & No. & $\mathbf{1}$ & $\mathbf{2}$ & $\mathbf{3}$ & $\mathbf{4}$ & $\mathbf{5}$ & $\mathbf{6}$ & $\mathbf{7}$ \\
\hline Employee Engagement & 1 & 1 & $.186^{* *}$ & -0.049 & $.207^{* *}$ & $.375^{* *}$ & $-.279^{* *}$ & .040 \\
Salary Satisfaction & 2 & & 1 & $.670^{* *}$ & $-.215^{* *}$ & $.550^{* *}$ & $.314^{* *}$ & $.558^{* *}$ \\
Employee Recognition & 3 & & & 1 & 0.044 & $.492^{* *}$ & $.304^{* *}$ & $.549^{* *}$ \\
Job tenure & 4 & & & & 1 & 0.001 & $.128^{* *}$ & $.127^{* *}$ \\
Education & 5 & & & & & 1 & $.341^{* *}$ & $.636^{* *}$ \\
Employee level & 6 & & & & & & 1 & $.656^{* *}$ \\
Job income & 7 & & & & & & & 1 \\
\hline
\end{tabular}

$* * p<0.001$

This study found a negative influence of employee recognition on employee engagement in the sample of bank employees. This result is a counterintuitive outcome suggesting that employee engagement decreases as recognition increases. It is the contrast of the evidence provided by some studies conducted both in developed and developing countries. In Ghana, for example, Akafo and Boateng (2015) found that employee recognition has a positive influence on employee engagement. Danish and Usman (2010) in India also found a positive effect of employee recognition on employee engagement in a sample of employees from different industrial sectors. Apparently, the current study's finding opposes most of the evidence in the literature. The result may be attributed to the fact that employee behaviour can grow worse and detrimental to the organization if compensation, recognition and reward procedures run counter to employee needs (Mansoor et al., 2015). It could also be due to the fact that the bank was recovering from its merger with reshuffling of management, new policies, unfavourable change in salary scales etc as observed by (Mussie et al., 2013). 
INTERNATIONAL JOURNAL OF ACADEMIC RESEARCH IN ACCOUNTING, FINANCE AND

MANAGEMENT SCIENCES

Vol. 11, No. 3, 2021, E-ISSN: 2225-8329 @ 2021 HRMARS

Table 4. The association between salary satisfaction, employee engagement and employee recognition

\begin{tabular}{|c|c|c|c|c|c|c|c|}
\hline $\begin{array}{l}\text { Dependent } \\
\text { variable }\end{array}$ & Path & $\begin{array}{l}\text { Independent } \\
\text { variable }\end{array}$ & $\begin{array}{l}\text { Unstandardized } \\
\text { B }\end{array}$ & $\begin{array}{l}\text { Standardised } \\
\beta\end{array}$ & $\begin{array}{l}\text { Std. } \\
\text { Error }\end{array}$ & $T$ & $P$ \\
\hline \multicolumn{8}{|l|}{ Main effect } \\
\hline $\begin{array}{l}\text { Salary satisfaction } \\
\text { Employee }\end{array}$ & $<---$ & $\begin{array}{l}\text { Employee } \\
\text { recognition } \\
\text { Employee }\end{array}$ & 0.922 & 0.67 & 0.048 & 19.237 & $* * *$ \\
\hline $\begin{array}{l}\text { engagement } \\
\text { Employee }\end{array}$ & $<---$ & $\begin{array}{l}\text { recognition } \\
\text { Salary }\end{array}$ & -0.293 & -0.47 & 0.028 & -10.36 & $* * *$ \\
\hline engagement & $<--$ & satisfaction & 0.206 & 0.46 & 0.022 & 9.167 & $* * *$ \\
\hline \multicolumn{8}{|l|}{ Covariate effect } \\
\hline Employee & & & & & & - & \\
\hline $\begin{array}{l}\text { engagement } \\
\text { Employee }\end{array}$ & $<---$ & Employee level & -0.499 & -0.49 & 0.043 & 11.598 & $* * *$ \\
\hline $\begin{array}{l}\text { engagement } \\
\text { Employee }\end{array}$ & $<---$ & Job tenure & 0.186 & 0.39 & 0.017 & 11.158 & $* * *$ \\
\hline $\begin{array}{l}\text { engagement } \\
\text { Employee }\end{array}$ & $<---$ & Education & 0.545 & 0.53 & 0.045 & 12.217 & $* * *$ \\
\hline $\begin{array}{l}\text { engagement } \\
\text { Employee }\end{array}$ & $<---$ & Job income & -0.007 & -0.02 & 0.021 & -0.356 & 0.722 \\
\hline $\begin{array}{l}\text { recognition } \\
\text { Employee }\end{array}$ & $<---$ & Employee level & -0.107 & -0.07 & 0.083 & -1.29 & 0.197 \\
\hline $\begin{array}{l}\text { recognition } \\
\text { Employee }\end{array}$ & $<---$ & Job tenure & -0.003 & 0.00 & 0.03 & -0.114 & 0.91 \\
\hline $\begin{array}{l}\text { recognition } \\
\text { Employee }\end{array}$ & $<---$ & Education & 0.382 & 0.23 & 0.083 & 4.608 & $* * *$ \\
\hline recognition & $<---$ & Job income & 0.265 & 0.45 & 0.037 & 7.133 & $* * *$ \\
\hline
\end{tabular}

$* * * p<0.001$

From Table 4, employee recognition caused a positive effect on salary satisfaction $[\beta=0.67$; $t=19.237 ; p<.0000]$ and made a negative effect on employee engagement $[\beta=-0.47 ; t=-10.36$; $p<.0000]$. This meant that salary satisfaction increased as employee recognition also increased whereas employee engagement decreased as employee recognition increased. Salary satisfaction also made positive impact on employee engagement $[\beta=0.46$; $t=9.167$; $p<.0000]$. This tells us that employee engagement increases as salary satisfaction also increases. In addition, it was confirmed from the results that employee engagement decreased as employee level increased. Also, an increase in job tenure increases employee engagement. Last but not least, employee engagement as well as employee recognition will increase with education. Thus, education has positive effect on both employee engagement and recognition.

The result of the study indicates that employee recognition makes a positive effect on salary satisfaction in the sample of employees. This outcome implies that employees' satisfaction with their salaries increases as their recognition is improved. This finding is consistent with some international studies (A'yuninnisa \& Saptoto, 2015). In Indonesia, for instance, $A^{\prime} y u n i n n i s a$ and Saptoto found that employee recognition makes a positive influence on 
MANAGEMENT SCIENCES

Vol. 11, No. 3, 2021, E-ISSN: 2225-8329 @ 2021 HRMARS

employee engagement. In this study, the researchers assumed that engagement was as a result of salary satisfaction and therefore concluded that employee engagement increases as a result of salary satisfaction. A more precise account was provided by Salleh and Memon (2015), who found out that employee recognition, was positively associated with salary satisfaction. Management of the bank can, therefore, benefit from strengthening employee recognition by aligning it with employee needs and interests. Owing to lessons from the first hypothesis (the result that employee recognition makes a negative effect on employee engagement), the main contribution of this study implied by a confirmation of the second hypothesis is the fact that employee recognition efforts in the bank and possibly other organizations need to consider the needs and opinions of employees to result in positive employee behaviours such as commitment and engagement. This study confirmed the positive association between salary satisfaction and employee engagement, which meant that employee engagement increased as salary satisfaction increased. In other words, employees are more strongly attached to their organization when their satisfaction with their salaries increases in line with most previous studies (Preko \& Adjetey, 2014; Salleh \& Memon, 2015; Vorina et al., 2017).

The Interaction influence of employee recognition and salary satisfaction on employee engagement is presented in Table 5. The interaction term "recognition $x$ satisfaction" showed a significant positive effect in the model. Salary satisfaction interacted in the relationship between employee recognition and the first three covariate factors (job tenure, education and employee level) by making a change in this relationship. Salary satisfaction had an effect on employee recognition. With regard to collinearity statistics, the tolerance value was greater than 0.10 which meant there was no multicollinearity among independent variables. About $40 \%$ of the dependent variable was explained by the independent variables. The remaining $60 \%$ was unexplained. The result is in support of the fourth hypotheses and signifies two main practical contributions of the study. First, it is ideal to meet all job needs according to the TTM to maximise performance, but it might be necessary for organizations, in cost-optimising situations, to focus on meeting needs that can positively affect multiple employee behaviours (Asiamah et al., 2018; Mends-Brew \& Asiamah, 2018;). 
INTERNATIONAL JOURNAL OF ACADEMIC RESEARCH IN ACCOUNTING, FINANCE AND

MANAGEMENT SCIENCES

Vol. 11, No. 3, 2021, E-ISSN: 2225-8329 @ 2021 HRMARS

Table 5. Interaction influence of employee recognition and salary satisfaction on employee engagement

\begin{tabular}{|c|c|c|c|c|c|c|c|c|}
\hline Variable & & $\begin{array}{c}\text { Unstandardized } \\
\text { B }\end{array}$ & S.E. & $\begin{array}{c}\text { Standardized } \\
\beta \\
\end{array}$ & $T$ & $95 \% \mathrm{Cl}$ & Tol. & VIF \\
\hline \multicolumn{9}{|l|}{ Main effect } \\
\hline $\begin{array}{l}\text { Recognition } \\
\text { Satisfaction } \\
\text { Covariate effect }\end{array}$ & $x$ & 0.001 & 0.004 & 0.214 & $3.286^{*}$ & \pm 0.014 & 0.542 & 1.845 \\
\hline Job tenure & & 0.13 & 0.018 & 0.274 & $7.295^{* *}$ & \pm 0.070 & 0.948 & 1.055 \\
\hline Education & & 0.564 & 0.051 & 0.557 & $11.003^{* *}$ & \pm 0.202 & 0.521 & 1.921 \\
\hline Employee level & & -0.48 & 0.049 & -0.48 & $-9.727 * *$ & \pm 0.193 & 0.549 & 1.822 \\
\hline Job income & & -0.016 & 0.024 & -0.043 & -0.659 & \pm 0.093 & 0.32 & 3.121 \\
\hline \multicolumn{9}{|l|}{ Model fit } \\
\hline $\mathrm{R}^{2}$ & & 0.400 & & & & & & \\
\hline Adjusted $\mathrm{R}^{2}$ & & 0.393 & & & & & & \\
\hline Change in $\mathrm{R}^{2}$ & & 0.007 & & & & & & \\
\hline Durbin-Watson & & 1.631 & & & & & & \\
\hline $\mathrm{F}$ & & 59.882 & & & & & & \\
\hline$P$ & & 0.000 & & & & & & \\
\hline
\end{tabular}

${ }^{* *} p<0.001$. Note: S.E. = standard error; $\mathrm{Cl}=$ confidence interval; Tol. = tolerance; $\mathrm{VIF}=$ variance inflation factor

\section{Conclusion}

The study was set up to investigate the Influence of Employee Recognition on Employee Engagement and the Moderating Role of Salary Satisfaction. The objectives were to analyze the influence of employee recognition on employee engagement; examine the association between employee recognition and salary satisfaction; assess the influence of salary satisfaction on employee engagement and analyze the moderation influence of employee recognition and salary satisfaction on employee engagement. It was concluded from the study that, when the bank increases its recognition for employees in addition to other intrinsic and extrinsic factors, employee engagement may increase, enabling employees to make more contribution to growth. Similarly, employees' salary satisfaction increased when the bank accorded them higher recognition. Employees are more strongly engaged in the bank when their salary satisfaction increases. The influence of employee recognition on employee engagement is stronger in light of salary satisfaction. Thus, salary satisfaction uniquely increases employee engagement in that increasing it in the bank is an opportunity to maximise the impact of employee recognition on employee engagement. Thus, increasing employee recognition and salary satisfaction is an effective way to improve staff engagement in the bank. This study found a negative influence of employee recognition on employee engagement. The evidence consequently suggests the need for a more elaborate assessment of the relationship using a national or completely representative sample in future research.

\section{Theoretical and Contextual Contribution of this Research to Existing Knowledge}

The practical significance of the study is glaring given the level of competition in the banking sector and how crucial it is for banks to maximise employee engagement. This study was 
MANAGEMENT SCIENCES

Vol. 11, No. 3, 2021, E-ISSN: 2225-8329 @ 2021 HRMARS

expected to unfold areas of recognition that must be improved to enhance employee recognition. Because new policies and decisions on employee recognition may trigger mixed reactions and behaviours in the bank, the current study was expected to tell management what can be done to improve staff engagement. Considering the level of instability in the banking sector in Ghana, banks need innovation and unique strategies to succeed. Stronger employee engagement is necessary if special strategies should be developed by the banks. This study provided recommendations towards enhancing employee engagement to maximise their commitment to strategy formulation and their productivity in it. Employee recognition is a crucial part of motivation. Many researchers recognize this role of employee recognition in Human Resource practice and have therefore undertaken various studies on it (Mussie et al., 2013). Despite this crucial role played by this variable however, in research and practice, no scale has been developed to measure it in Ghana. Upon systematically reviewing the literature, the researcher realized that no related study on the current topic has adjusted for confounding variables. Theoretically, this study is significant for the reason that this is the first time, the moderating role of salary satisfaction in the relationship between employee recognition and employee engagement has been tested, giving the researcher the opportunity to establish a theoretical stance explaining how salary satisfaction can depend on employee recognition to drive employee engagement. Also, the indirect influence of salary satisfaction on employee engagement is theoretically explained. In this regard, the study demonstrates how theories can be used for different contexts and in understanding practical problems. This study is the first to validate a scale for measuring employee recognition in Ghana, thereby providing a tool for future researchers to use.

\section{Limitations of the study}

The study was limited by non availability and unwillingness of some respondents to participate due to time and other personal reasons. Time and financial constraints did not permit the study to consider all Banks but to select a few.

\section{Acknowledgement}

We wish to thank Dr. Hannah Vivian Osei, Dr. (Mrs.) Felicity Asiedu-Appiah, Dr. (Mrs.) Rosemary Coffie, Dr. Henry Mensah and Dr. Jonathan Annan who collectively contributed immensely towards my training at KNUST. We are grateful to the entire staff of the Department of Human Resource \& Organizational Development and all others who advised me in the field of research and for their immense contribution towards the completion of this work especially Mr. Nestor Asiamah. Lastly, we are grateful to Dr. Manfred B. Ewool formerly of CSIR-Crops Research Institute and Mrs. Felicia Ewool as well as Rev. Dr. Albert B. Kwabi \& wife Mrs. Theresa Kwabi for their financial support in the conduct and publication of this study.

\section{References}

Akafo, V., \& Boateng, P. A. (2015). Impact of Reward and Recognition on Job Satisfaction and Motivation, European Journal of Business and Management, 24(7): 112-124.

Asiamah, N. (2017). The nexus between health workers' emotional intelligence and job performance Controlling for gender, education, tenure and in-service training, Journal of Global Responsibility, 8(1): 1-16. 
MANAGEMENT SCIENCES

Vol. 11, No. 3, 2021, E-ISSN: 2225-8329 ๔ 2021 HRMARS

Asiamah, N., Mends-Brew, E., \& Boison, B. K. T. (2019). A spotlight on cross-sectional research: Addressing the issues of confounding and adjustment, International Journal of Healthcare Management, 12(4): 1-14.

Asiamah, N., Mensah, H. K., \& Danquah, E. (2018). An assessment of the emotional intelligence of health workers: A scale validation approach, Journal of Global Responsibility, 9(2): 141-159

A'yuninnisa, R. N., \& Saptoto, R. (2015). The effects of pay satisfaction and affective commitment on turnover intention, International Journal of Research Studies in Psychology, 2(4): 57-70.

Baskar \& Prakash, R. (2015). A Study on the Impact of Rewards and Recognition on Employee Motivation, International Journal of Science and Research, 4(11): 16441647

Danish, R. Q., \& Usman, A. (2010). Impact of Reward and Recognition on Job Satisfaction and Motivation: An Empirical Study from Pakistan, International Journal of Business and Management, 2(5): 159-167.

Ghana Banking Survey. (2015). Bank of the Future: What bank customers want to experience by 2020. Retrieved from https://www.pwc.com/gh/en/assets/pdf/2015banking-survey.pdf

Kelava, A. (2016). A Review of Confirmatory Factor Analysis for Applied Research (Second Edition), Journal of Educational and Behavioral Statistics, 20(10): 1-5.

Kimutai, K. A., \& Sakataka, W. (2015). Effect of Reward on Employee Engagement and Commitment at Rift Valley Bottlers Company, International Academic Journal of Human Resource and Business Administration, 5(1): 36-54.

Korir, I., \& Kipkebut, D. (2016). The Effect of Reward Management on Employees Commitment in the Universities in Nakuru County-Kenya, Journal of Human Resource Management, 4(4): 37-48.

Malik, M. E., Danish, R. Q., \& Munir, Y. (2012). The Impact of Pay and Promotion on Job Satisfaction: Evidence from Higher Education Institutes of Pakistan, American Journal of Economics, Special Issue: 6-9.

Mansoor, R., Ahmad, N., Hussain, A., \& Hameed, M. (2015). Impact of Rewards on Job Satisfaction Evidences from Telecom Sector of Pakistan, Arabian Journal of Business and Management Review (OMAN Chapter), 11(4): 47-60.

Mends-Brew, E., \& Asiamah, N. (2018). Improving health workers' organizational commitment: Drawing lessons from the interaction between internal marketing and key job characteristics, International Journal of Healthcare Management, 4(11): 1-11.

Mensah, H. K., Asiamah, N., Mireku, K. (2016). The effect of organizational justice delivery on organizational commitment, Journal of Global Responsibility, 7(2): 196-209.

Muchai, M. M., \& Benson, M. (2014). Effect of Employee Rewards and Recognition on Job Performance in Kenya's Public Sector, A Case Study of Nakuru Water and Sanitation Services Company Ltd, International Journal of Science and Research (IJSR), 9(3): 21512156.

Mussie, T. T., Kathryn, J. R., \& Embaye, A. B. (2013). The Effects of Employee Recognition, Pay, and Benefits on Job Satisfaction: Cross Country Evidence, Journal of Business and Economics, 4(1): 1-12.

Ndungu, D. N. (2017). The Effects of Rewards and Recognition on Employee Performance in Public Educational Institutions: A Case of Kenyatta University, Kenya, Global Journal of Management and Business Research: Administration and Management, 17(1): 43-68. 
Preko, A., \& Adjetey, J. (2013). A Study on the Concept of Employee Loyalty and Engagement on the Performance of Sales Executives of Commercial Banks in Ghana, International Journal of Business Research and Management (IJBRM), 2(4): 51-62.

Shonubi, O. A., Abdullah, N., Hashim, R. \& Hamid, N. B. A. (2016). Recognition and Appreciation and the Moderating Role of Self-esteem on Job Satisfaction and Performance among IT Employees in Melaka, Journal of Health Science, 4: 221-227.

Salleh, R., \& Memon, M. A. (2015). A Review on the Effects of Pay Satisfaction on Employee Engagement and Turnover: A Proposed Mediating Framework, International Business Management, 9(3): 344-348.

Salisu, J. B., Chinyio, E., \& Suresh, S. (2015). The impact of compensation on the job satisfaction of public sector construction workers of jigawa state of Nigeria, The Business and Management Review, 4(6): 282-296.

Vorina, A., Simonič, M., \& Vlasova, M. (2017). An Analysis of the Relationship Between Job Satisfaction and Employee Engagement, Economic Themes, 55(2): 243-262.

Yaseen, A. (2013). Effect of Compensation Factors on Employee Satisfaction- A Study of Doctor's Dissatisfaction in Punjab, International Journal of Human Resource Studies, 3(1): 142-157. 
MANAGEMENT SCIENCES

Vol. 11 , No. 3, 2021, E-ISSN: 2225-8329 @ 2021 HRMARS

\section{Appendix}

Kwame Nkrumah University of Science and Technology (KNUST)

KNUST School of Business

Department of Human Resource \& Organizational Development

The purpose of this study is to explore the nexus between salary satisfaction, employee engagement and employee recognition. This study will suggest policies for compensating employees in manner that support their maximum inclusiveness in the organisation. You are one of the individuals found eligible to respond in this study, and you are therefore entreated to respond to this questionnaire in an objective and transparent manner. The study is for academic purposes only; hence you can rest assured that your responses shall be treated confidential. Respond to all questions by ticking your choice or writing your view. Thank you for your involvement in this study.

\section{SECTION A: SALARY SATISFACTION}

The following statements relate to your pay satisfaction in this organisation. Kindly use a 7point Likert scale measuring from " $1=$ not satisfied" to " $7=$ extremely satisfied" to indicate how satisfied you are with your salary or pay in this company. The full-scale definition is as follows:

Not satisfied $\quad-1$

Almost satisfied $\quad-2$

Least satisfied $\quad-3$

Somewhat satisfied -4

Satisfied $\quad-5$

Very satisfied $\quad-6$

Extremely satisfied $\quad-7$ 
INTERNATIONAL JOURNAL OF ACADEMIC RESEARCH IN ACCOUNTING, FINANCE AND

MANAGEMENT SCIENCES

Vol. 11, No. 3, 2021, E-ISSN: 2225-8329 @ 2021 HRMARS

\begin{tabular}{|c|c|c|c|c|c|c|c|c|}
\hline No. & Statement & 1 & 2 & 3 & 4 & 5 & 6 & 7 \\
\hline \multicolumn{9}{|c|}{ To what extent are you satisfied with... } \\
\hline 1 & Your current salary & & & & & & & \\
\hline 2 & Your overall level of pay & & & & & & & \\
\hline 3 & Size of your current salary & & & & & & & \\
\hline 4 & Your take-home pay & & & & & & & \\
\hline 5 & Your benefit packages & & & & & & & \\
\hline 6 & The value of your benefits & & & & & & & \\
\hline 7 & Amount the company pays toward your benefits & & & & & & & \\
\hline 8 & The number of benefits I receive & & & & & & & \\
\hline 9 & Your most recent raise & & & & & & & \\
\hline 10 & Influence your supervisor has over your pay & & & & & & & \\
\hline 11 & The raises I have typically received in the past & & & & & & & \\
\hline 12 & How your raises are determined & & & & & & & \\
\hline 13 & The company's pay structure & & & & & & & \\
\hline 14 & $\begin{array}{l}\text { Information the company gives about pay issues is of concern to } \\
\text { me }\end{array}$ & & & & & & & \\
\hline 15 & Pay of other jobs in the company & & & & & & & \\
\hline 16 & Consistency of the company's pay policies & & & & & & & \\
\hline 17 & Differences in pay among jobs in the company & & & & & & & \\
\hline 18 & How the company administers pay & & & & & & & \\
\hline
\end{tabular}

19. What else can you say about your salary in this organisation?

\section{SECTION B: EMPLOYEE ENGAGEMENT}

The following items measure your level of engagement in this organisation's activities. Kindly use a 5-point Likert scale measuring from "1= strongly disagree" to "5= strongly agree" to indicate the degree to which you agree to the statements. The full-scale definition is as follows:

Strongly disagree $\quad-1$

Disagree $\quad-2$

Not sure/Neutral -3

Agree $\quad-4$

Strongly agree $\quad-5$ 
INTERNATIONAL JOURNAL OF ACADEMIC RESEARCH IN ACCOUNTING, FINANCE AND

MANAGEMENT SCIENCES

Vol. 11, No. 3, 2021, E-ISSN: 2225-8329 @ 2021 HRMARS

\begin{tabular}{|c|c|c|c|c|c|c|}
\hline No. & Statement & 1 & 2 & 3 & 4 & 5 \\
\hline 1 & I work with intensity on my job. & & & & & \\
\hline 2 & I exert my full effort to my job. & & & & & \\
\hline 3 & I devote a lot of energy to my job. & & & & & \\
\hline 4 & I try my hardest to perform well on my job & & & & & \\
\hline 5 & I strive as hard as I can to complete my job. & & & & & \\
\hline 6 & I exert a lot of energy on my job. & & & & & \\
\hline 7 & I am enthusiastic about my job. & & & & & \\
\hline 8 & I feel energetic about my job. & & & & & \\
\hline 9 & I am interested in my job. & & & & & \\
\hline 10 & I am proud of my job. & & & & & \\
\hline 11 & I feel positive about my job. & & & & & \\
\hline 12 & I am excited about my job. & & & & & \\
\hline 13 & At work, my mind is focused on my job. & & & & & \\
\hline 14 & At work, I pay a lot of attention to my job. & & & & & \\
\hline 15 & At work, I concentrate on my job. & & & & & \\
\hline 16 & At work, I focus a great deal of attention on my job. & & & & & \\
\hline 17 & At work, I am absorbed in my job. & & & & & \\
\hline 18 & At work, I devote a lot of attention to my job. & & & & & \\
\hline
\end{tabular}

19. What else can you say about your engagement with this organisation?

\section{SECTION C: EMPLOYEE RECOGNITION}

The following items measure your opinions about employee recognition in this organisation. Kindly use a 5-point Likert scale measuring from "1= strongly disagree" to "5 = strongly agree" to indicate the degree to which you agree to the statements. The full-scale definition is as follows:

Strongly disagree $\quad-1$

Disagree $\quad-2$

Not sure/Neutral $\quad-3$

Agree $\quad-4$

Strongly agree -5 
INTERNATIONAL JOURNAL OF ACADEMIC RESEARCH IN ACCOUNTING, FINANCE AND MANAGEMENT SCIENCES

Vol. 11 , No. 3, 2021, E-ISSN: 2225-8329 @ 2021 HRMARS

\begin{tabular}{|c|c|c|c|c|c|c|}
\hline No. & Statement & 1 & 2 & 3 & 4 & 5 \\
\hline 1 & The work I do in this organisation is appreciated & & & & & \\
\hline 2 & My payback and benefits are a good return for my efforts & & & & & \\
\hline 3 & I am given ample non-monetary benefits owing to my work & & & & & \\
\hline 4 & $\begin{array}{l}\text { I am satisfied with my organisation's current recognition } \\
\text { program }\end{array}$ & & & & & \\
\hline 5 & $\begin{array}{l}\text { The nature of my job allows me adequate opportunity to be } \\
\text { recognized }\end{array}$ & & & & & \\
\hline 6 & I believe that all employees are equally rewarded & & & & & \\
\hline 7 & $\begin{array}{l}\text { I think employees are rewarded adequately below and above } \\
\text { normal duties }\end{array}$ & & & & & \\
\hline
\end{tabular}

8. What other comments can you make about this organisation's employee recognition program?

\section{SECTION D: DEMOGRAPHIC VARIABLES}

1. What is your gender?

Male [ ]

Female[ ]

2. How long have you been working in this bank?

Less than 3 months []

3-5 months []

6-10 months []

10-12 months []

3. How long have you been working in your field of profession?

Less than 3 years

3-5 years

6-10 years

[]

Above 10 years

4. What is your highest educational qualification

Pre-tertiary qualification

Diploma/HND

[ ]

First degree

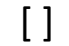

Master's degree

[ ]

PhD or equivalent

Others (specify)

5. What is your employee level?

Lower level

Middle level 
INTERNATIONAL JOURNAL OF ACADEMIC RESEARCH IN ACCOUNTING, FINANCE AND MANAGEMENT SCIENCES

Vol. 11, No. 3, 2021, E-ISSN: 2225-8329 @ 2021 HRMARS

Top/senior level

6. Kindly choose the group in which your current gross income (in Ghana cedis) falls Less than 1,000

$1,000-2,000$

$2,001-3,000$

$3,001-4,000$

$4,001-5,000$

Above 5,000

[ ]

[ ]

[ ]

[ ]

[]

[ ]

7. To which of the following age groups do you belong?

$\begin{array}{ll}10-20 & \text { [ ] } \\ 21-30 & {[]} \\ 31-40 & {[]} \\ 41-50 & {[]} \\ 51-60 & \text { [ ] } \\ \text { Above 60 } & \text { [ ] }\end{array}$

THANK YOU FOR YOUR RESPONSE 